\title{
Pathologic Examination of the Protective Effect of Glycyrrhizin on Cyclophosphamide-induced Hemorrhagic Cystitis in Rats
}

\author{
Okan ERDOĞAN1, Hikmet KELEŞ2* \\ ${ }^{1}$ Banaz Distinc Health Directorate, 64500, Usak, TURKEY \\ ${ }^{2}$ Afyon Kocatepe University, Faculty of Veterinary Medicine, Department of Pathology, 03030, Afyonkarahisar, TURKEY
}

\begin{abstract}
Cyclophosphamide (CP) is a widely used anti-neoplastic agent in humans and small animals and also has some adverse effects in them. The most common adverse effect of CP is hemorrhagic cystitis (HS). The use of Mesna may prevent HS, but is insufficient for some side effects. In this study, the effect of glycyrrhizin (GLY), which is one of the active substances of licorice root, was examined against CP-related side effects. The experiment was designed with 49 male Sprague Dawley rats. The Control group received only physiological saline and the CP group only CP. CP+Mesna group received CP and also three dose of Mesna. The animals in the CP+GLY100 and CP+GLY200 groups were received three doses of GLY, $100 \mathrm{mg} / \mathrm{kg}$ and $200 \mathrm{mg} / \mathrm{kg}$ dose, respectively. The previous protocol was applied to the CP+Mesna+GLY100 and CP+Mesna+GLY200 groups and only the first GLY application was replaced with Mesna. In this study, it was recorded that bladder macroscopy and histopathology were better preserved in GLY applicated groups compared to CP group. However, it was observed that this protection was slightly weaker than the Mesna and GLY-Mesna combinations. From this point of view, it was observed that GLY could be preventive in CP-related HS, in addition it could also support to Mesna applications.
\end{abstract}

Keywords: Cyclophosphamide, Glycyrrhizin, Hemorrhagic cystitis, Mesna, Pathology

\section{Ratlarda Siklofosfamid ile İndüklenen Hemorajik Sistitisde Glycyrrhizinin Koruyucu Etkilerinin Patolojik Olarak İncelenmesi}

ÖZ

Siklofosfamid (CP) yaygin olarak kullanılan bir anti-neoplastik ajandır ve bazı yan etkilere sahiptir. Siklofosfamidin en belirgin yan etkisi hemorajik sistitistir (HS). Mesna kullanımı HS'yi önleyebilmekte ancak diğer bazı yan etkiler için yetersiz kalmaktadır. Bu çalışmada, CP ilişskili HS’ye karşı, meyan kökünün aktif içeriklerinden olan glycyrrhizinin (GLY) etkisi incelenmiştir. Çalışma, 49 adet, erkek Sprague Dawley rat ile dizayn edilmiştir. Kontrol grubuna sadece fizyolojik tuzlu su, CP grubuna ise sadece CP verilmiştir. CP+Mesna grubuna CP ve ayrıca 3 doz Mesna uygulanmıştır. CP+GLY100 ve CP+GLY200 gruplarına; CP ve sırasıyla $100 \mathrm{mg} / \mathrm{kg}$ ile $200 \mathrm{mg} / \mathrm{kg}$ olmak üzere üç doz GLY uygulanmıştır. Bir önceki protokol CP+Mesna+GLY100 ve CP+Mesna+GLY200 gruplarınada uygulanmış olup sadece ilk GLY uygulaması Mesna ile değiştirilmiştir. Çalışmada GLY uygulanan gruplarda CP grubuna kıyasla mesane makroskobisi ve histopatolojisinin daha iyi bir şekilde korunmuş olduğu kaydedilmiştir. Ancak, bu korumanın Mesna ve GLY-Mesna kombinasyonlarına kıyasla biraz daha zayıf kaldığı izlenmiştir. Buradan yola çıkılarak GLY'in CP ilişkili HS'de önleyici olabileceği aynı zamanda Mesna uygulamalarına destek verebileceği kanaatine varılmıştır.

Anahtar Kelimeler: Glycyrrhizin, Hemorajik sistitis, Mesna, Patoloji, Siklofosfamid

To cite this article: Erdoğan O. Keles H. Pathologic Examination of the Protective Effect of Glycyrrbizin on Cyclophosphamide-induced Hemorrhagic Cystitis in Rats. Kocatepe Vet J. (2019) 12(1):89-96 


\section{INTRODUCTION}

Hemorrhagic cystitis (HS) is a complication that is difficult to treat and occurs due to different etiologies (Del Pizzo et al. 1998, Manikandan et al. 2010). Considering the cases, it is observed that cyclophosphamide (CP) and ifosfamide, which are used for chemotherapeutic purpose, play a leading role in the cause of HS (Philips et al. 1961, deVries and Freiha 1990, West 1997). In the chronological process, various methods have been tried to prevent and/or cure CP-associated HS, but success has been limited and changed for each patient (Ballen et al. 1999). In clinical medicine, Mesna (2-mercaptoethan sodium sulfonate) is mostly preferred to prevent CPassociated HS (Soysal 2004). Mesna, which may be ineffective in relieving some clinical, macroscopic and microscopic symptoms (Gressier et al. 1995), also has side effects such as allergic reactions, dermatosis and hypersensitivity in the skin (Khaw et al. 2007, Dorris et al. 2011, Lin and Keefe 2012).

In recent studies, a tendency towards plant and extracts has been clearly observed in order to prevent damage caused by CP-induced HS. In these applications, the active ingredient can be used alone or in combination with Mesna. Ankaferd Blood Stopper ${ }^{\circledR}$ is a product consisting of Thymus vulgaris, Glycyrrbiza glabra, Vitis vinifera, Alpinia officinarum, and Urtica dioica. This product, which is also used for blocking the bleeding, in other parts of the body, is also used against HS (Goker et al. 2008). Against the CP-induced urotoxicity, morning glory (Ipomoea obscura) (Hamsa and Kuttan 2011); ternatin (Vieira et al. 2004), a flavonoid extracted from chamomile (Egletes viscosa Less.);, curcumin, an extraction product of turmeric (Curcuma longa) (Arafa 2009); berberine (Xu and Malavé 2001) obtained from Berberis spp.,; active ingredients of Mandevilla (Mandevilla velutina) (Santos et al. 2010); Pyllanthus niruri plant (Boeira et al. 2011); resveratrol (Keles et al. 2014) extracted from grape seed,; ellagic acid (Kankaya 2017) found abundantly in blackberry, pomegranate and rosehip species, were found to be efficient in preventing HS in experimental studies in mice and rats.

Glycyrrbiza glabra plant, also known as "Meyan" in our country, is consumed in different ways (Asımgil 1997, Baytop 1999a, 1999b). One of the active agents of this plant is glycyrrhizine (GLY). Glycyrrhizin has been shown to have a therapeutic effect in neoplasias with various etiologies (Ito et al. 1988, Lin et al. 1999, Shiota et al. 1999, Sohn et al. 2003, Ram et al. 2006, Asl and Hosseinzadeh 2008, Kim et al. 2012, Park et al. 2013). Anti-coagulative (Assafim et al. 2006), antiinflammatory (Francischetti et al. 1997), antiedematous (Ohnishi et al. 2011), and antihemorrhagic (Ieong et al. 2018) properties were reported in GLY applications. Glycyrrhizin suppresses nitric oxide (NO) production and inducible nitric oxide synthase (iNOS) expression (Wang et al. 2011, Uto et al. 2012). It has been suggested that $\mathrm{NO}$ is responsible for CP-related bladder damage (Oter et al. 2004) and NO increase was reported in non-CP cases, especially in the urothelial damage and hemorrhage occurred areas (Keles et al. 2018).

There was no experimental or field study in which GLY was used against CP-related HS in the literature review. In this study and context, the protective effects of GLY against controlled HS were investigated pathologically.

\section{MATERIALS and METHODS}

Cyclophosphamide (CP) (Endoxan ${ }^{\circledR}, 150 \mathrm{mg} / \mathrm{kg}$ Eczacibasi Istanbul, Turkey), Mesna (Uromitexan ${ }^{\circledR}$, $400 \mathrm{mg}$, Eczacıbaşı Baxter, Turkey), and Glycyrrhizin (GLY) (Sigma, Cas 53956-04-0) were purchased commercially. This study was carried out at Afyon Kocatepe University Experimental Animal Research and Application Center with permission of AKUHADYEK-477-15. The animals were given ad libitum standard rodent feed and tap water during the experiment. They were housed in polycarbonate cages, maintained on 12-hours light/12-hours dark cycle at room temperature $\left(22 \pm 0.5^{\circ} \mathrm{C}\right)$ and in appropriate humid environment. The experiment was started at the end of the 7 day adjustment period.

In the study, 49 male Sprague Dawley rats (220-250 g) were divided into seven groups of seven rats each. Hemorrhagic cystitis model was created according to our previous study (Keles et al. 2014). The animals in the Control group were given only $2-\mathrm{ml}$ saline and the animals in the CP group were given $2 \mathrm{ml}$ of CP (150 $\mathrm{mg} / \mathrm{kg}$, i.p). CP+Mesna group was given CP (150 $\mathrm{mg} / \mathrm{kg}$, i.p.) and a total of $90 \mathrm{mg} / \mathrm{kg}$ Mesna was administered in three equal doses in 2-ml saline by i.p. The first injection was given 20 min before the CP injection, and the second and third injections were administered 4 and $8 \mathrm{~h}$ after $\mathrm{CP}$ injection, respectively. $C P+G L Y 100$ and $C P+G L Y 200$ groups were given CP $(150 \mathrm{mg} / \mathrm{kg}$, i.p.) and a total of 300 $\mathrm{mg} / \mathrm{kg}$ and $600 \mathrm{mg} / \mathrm{kg}$ GLY were administered by gastric gavage (g.g.) in three equal doses in 2-ml saline, respectively. The first gavage was given $20 \mathrm{~min}$ before the CP injection, and the second and third gavages were administered 4 and $8 \mathrm{~h}$ after $\mathrm{CP}$ injection. Same applications were made for $C P+$ Mesna + GLY100 and CP+Mesna + GLY200 groups but only the first GLY application was replaced with Mesna $(30 \mathrm{mg} / \mathrm{kg}$ i.p). After $48 \mathrm{~h}$ of HS induction, rats were killed by using injection of ketamine HCL $(80 \mathrm{mg} / \mathrm{kg}$, i.p.) and xylazine HCL $(10 \mathrm{mg} / \mathrm{kg}$, i.p.) 
Following an abdominal incision, the bladders were removed, emptied and fixed in $10 \%$ buffered formalin. Processed tissues were blocked with parafin, and then sectioned into $5-\mu \mathrm{m}$ sections and stained with hematoxylin and eosin (HE). These slides were examined under a light microscope (Nikon Eclipse Ci attached Kameram ${ }^{\circledR}$ Digital Image Analyze System) and graded as mild $(+)$, moderate $(++)$, and severe $(+++)$ for hemorrhage, desquamation, degeneration, inflammation, edema, and congestion.

\section{Statistical analysis}

At the end of the experiment, data with normal distribution was analyzed using one-way analysis of variance (ANOVA) and least significance difference (LSD) test were used to determine the statistical significance of the data. For statistical significance, $\mathrm{p}<0.05$ was accepted.

\section{RESULTS}

\section{Clinical and Macroscopical Results}

After drug applications, the animals were taken to the corners of the cage for a period of time. Compared to the Control group, an increase of water consumption and a limited decrease of feed consumption were recorded in the experimental groups. Furthermore, intense hematuria with hand manipulations especially in animals of CP group was observed.

No macroscopic findings were observed in the bladders of the animals in the Control group (Figure 1A). The animal in the CP group had thickened wall of bladder, hemorrhages on both mucosa and serosa (Figure 2A) and often had a coagulated blood mass in the lumen. The bladders of the animals in the $\mathrm{CP}+$ Mesna group were macroscopically similar to those in the Control group (Figure 3A). The bladders of animals in the CP+GLY100 group had a serosal, mucosal and luminal hemorrhages on the thicker bladder wall compared to the Control group, but the lesions were milder than the CP group (Figure 4A). The bladder findings of the animals in the CP+GLY 200 group were similar to the bladder findings of the animals in the CP+GLY 100 group, but were less severe (Figure 5A). The bladder findings of $\mathrm{CP}+$ Mesna+GLY100 group were much lighter than $\mathrm{CP}$ group. Lesions were less severe than CP+GLY100 and CP+GLY200 groups (Figure 6A). The bladder findings of the animals in the CP+Mesna+GLY200 Group were considerably mild compared to the CP group. The observed lesions were also lighter than the lesions detected in the CP+GLY100, CP+GLY200 and CP+Mesna+GLY100 groups. The bladders in this group were similar to the Control group and the $\mathrm{CP}+$ Mesna group (Figure 7A).

\section{Histopathological Results}

Microscopical examinations revealed degenerative and desquamative findings, as well as acute inflammatory changes in the bladder tissues with varying intensity of congestion, edema and hemorrhages.

The levels of congestion in the CP, CP+GLY100 and $\mathrm{CP}+\mathrm{GLY} 200$ groups were significantly higher than the Control group and other groups. In the CP+Mesna+GLY100 and CP+Mesna+GLY200 groups, the congestion was quite lesser compared to the $\mathrm{CP}+\mathrm{Mesna}$ group and even at the Control group level.

There were no signs of edema in the Control group and CP+Mesna+GLY100 groups. Significantly lower edema in the CP+GLY200 group was similar to the $\mathrm{CP}+\mathrm{Mesna}$ group. The most severe edema level was observed in the $\mathrm{CP}$ group. Compared to the $\mathrm{CP}$ group, the low edema in the CP+GLY200 group was relatively higher in the CP+GLY100 group.

No signs of hemorrhage were observed in the Control, CP+Mesna, CP+Mesna+GLY100 and CP+Mesna+GLY200 groups. The most severe hemorrhages occurred in the $\mathrm{CP}$ group. Mild hemorrhages were also observed in the CP+GLY100 and CP+GLY200 groups, but the difference between the groups was statistically insignificant.

While no signs of inflammation were observed in the Control, CP+Mesna+GLY100 and CP+Mesna+GLY200 groups, it was determined that the level of inflammation in $\mathrm{CP}+$ Mesna group was not statistically significant compared to the first three groups. However, it was noted that the level of inflammation in CP+GLY200, CP, and CP+GLY100 groups was statistically significant compared to other groups.

No degeneration signs were observed in the Control group and the most severe degenerative findings were observed in the CP group. It was observed that degeneration observed in CP+GLY100 and CP+GLY200 groups was statistically significant compared to $\mathrm{CP}+\mathrm{Mesna}$ group. The lowest level of degeneration was observed in CP+Mesna+GLY200 group and the degeneration level in this group decreased significantly compared to $\mathrm{CP}+$ Mesna group.

There was no statistically significant change in the level of desquamation between Control, $\mathrm{CP}+$ Mesna+GLY100, and CP+Mesna+GLY200 groups, whereas the increase in desquamation in $\mathrm{CP}$, $\mathrm{CP}+$ Mesna, CP+GLY100, and CP+GLY200 groups was statistically significant compared to these three groups (Table 1 and Figures 1B-7B). 
Table 1. Histopathological parameters in study groups

\begin{tabular}{lllllll}
\hline Groups & Hemorrhage & Desquamation & Degeneration & Inflammation & Edema & Congestion \\
& & & & & & \\
\hline Control & $0 \pm 0$ & $0,28 \pm 0,487$ & $0 \pm 0$ & $0 \pm 0$ & $0 \pm 0$ & $1,0 \pm 1,0$ \\
CP & $4,0 \pm 0,816$ & $2,42 \pm 1,40$ & $3,57 \pm 1,133$ & $3,28 \pm 0,951$ & $4,57 \pm 0,787$ & $3,85 \pm 1,215$ \\
CP+M & $0 \pm 0$ & $1,71 \pm 0,951$ & $1,71 \pm 1,253$ & $0,14 \pm 0,377$ & $0,71 \pm 1,496$ & $2,14 \pm 0,899$ \\
CP+GLY100 & $3,5 \pm 1,397$ & $1,71 \pm 0,487$ & $2,0 \pm 0$ & $3,14 \pm 1,676$ & $4,0 \pm 0,577$ & $3,71 \pm 0,487$ \\
CP+GLY200 & $3,28 \pm 0,756$ & $2,42 \pm 1,397$ & $2,71 \pm 0,755$ & $3,43 \pm 0,534$ & $3,57 \pm 0,534$ & $3,0 \pm 0,577$ \\
CP+M+GLY100 & $0 \pm 0$ & $0 \pm 0$ & $1,0 \pm 0$ & $0 \pm 0$ & $0 \pm 0$ & $1,28 \pm 0,487$ \\
CP+M+GLY200 & $0 \pm 0$ & $0,14 \pm 1,299$ & $0,43 \pm 0,534$ & $0 \pm 0$ & $0,14 \pm 0,378$ & $1,28 \pm 0,487$ \\
\hline Alvalues & & & & &
\end{tabular}

All values are given as mean \pm standard deviation. $\mathrm{p}<0.05$
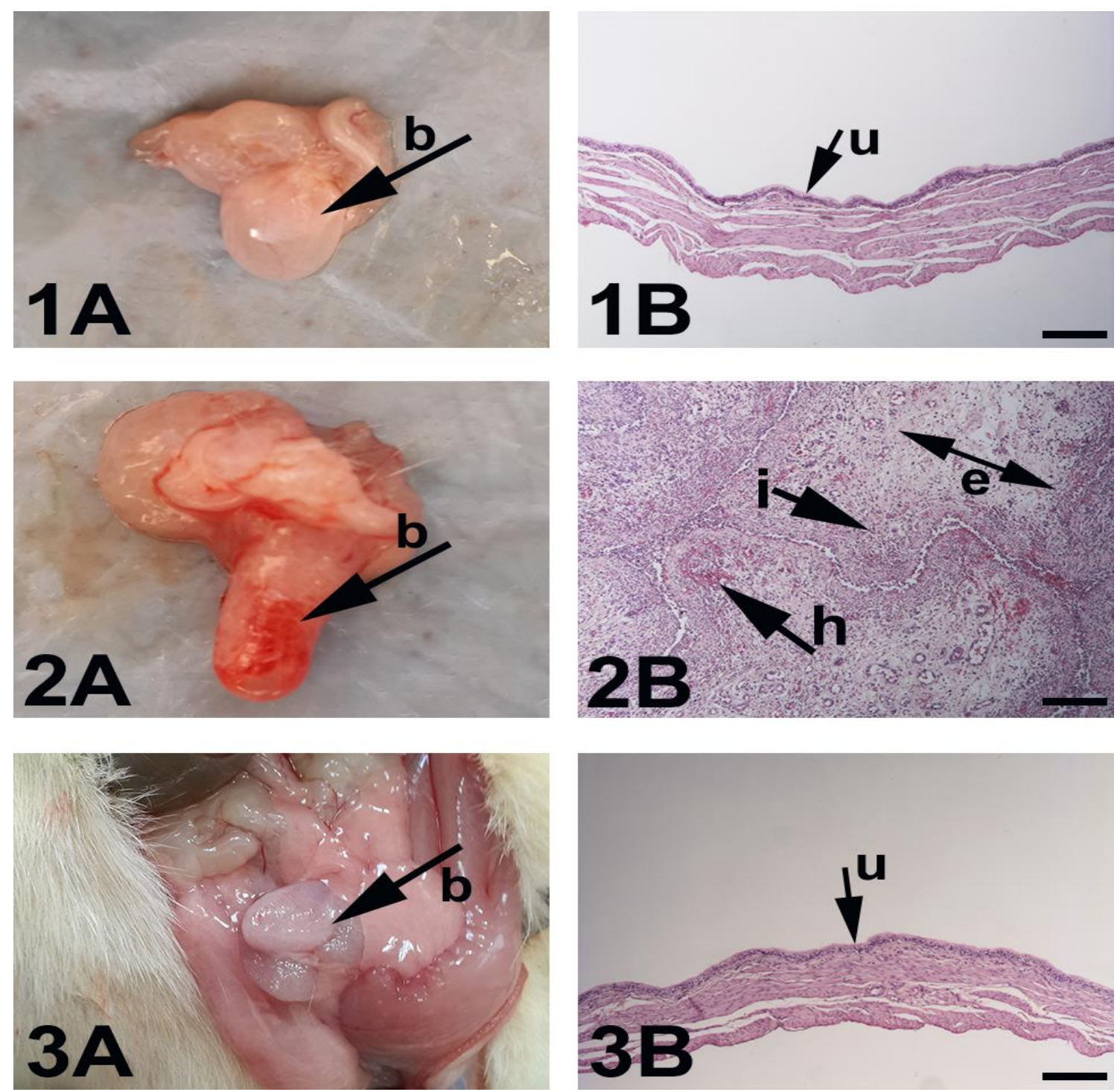

Figure 1A-3A. Bladder macroscopy (left column) of CP, Control, and CP+Mesna groups. 1A-Control Group: normal macroscopic appearance. 2A-CP Group: thickened wall and serosal hemorrhages. Coagulated blood and mucosal hemorrhages were observed in the lumen. 3A-CP+Mesna Group: any macroscopic lesion.

Figure 1B-3B. Bladder histology (right column) of CP, Control, and CP+Mesna groups. Scale bar is $200 \mu \mathrm{m}$ in the hematoxylin-eosin stained figures. Arrows pointing events; b:bladder, u:urothelium, i:inflammation, e:edema, h:hemorrhage 1B-Control Group: normal histological view of bladder. 2B-CP Group: severe congestion, hemorrhages, edema, inflammation, degeneration, and desquamation. 3B-CP+Mesna Group: histological view of normal bladder. 

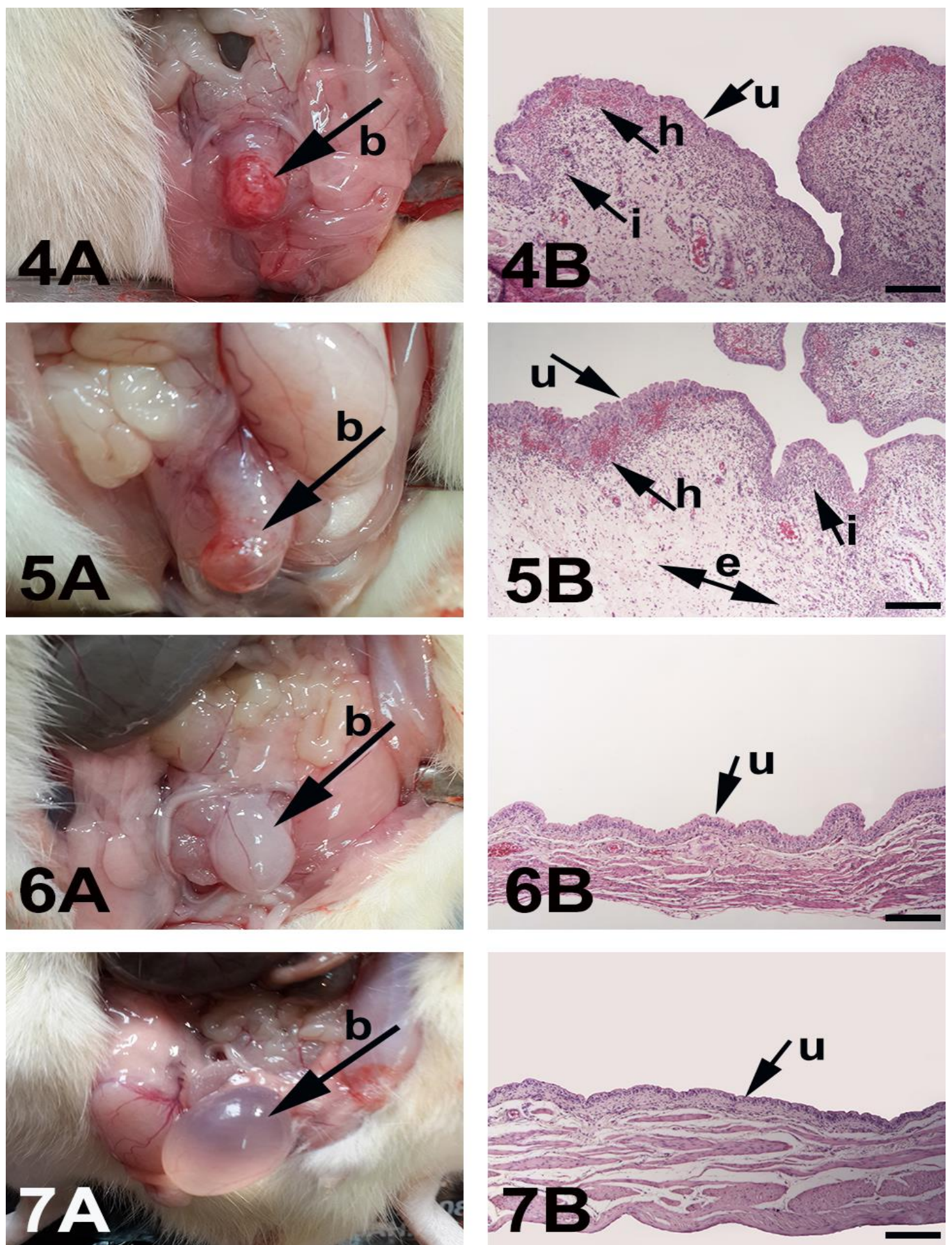

Figure 4A-7A. Bladder macroscopy (left column) of CP+GLY100, CP+GLY200, CP+Mesna+GLY100, and CP+Mesna+GLY200 groups. 4A-CP+GLY100 Group: thickened wall, serosal and mucosal hemorrhages. 5ACP+GLY200 Group: lighter lesions, similar to CP+GLY100 group. 6A-CP+Mesna+GLY100 Group: significantly lighter hemorrhagic and edematous lesions. 7A-CP+Mesna+GLY200 Group: the best macroscopic appearance, similar to Control and CP+Mesna groups.

Figure 4B-7B. Bladder histology (right column) of CP+GLY100, CP+GLY200, CP+Mesna+GLY100 and $\mathrm{CP}+$ Mesna+GLY200 groups. Scale bar is $200 \mu \mathrm{m}$ in the hematoxylin-eosin stained figures. Arrows pointing events; b:bladder, u:urothelium, i:inflammation, e:edema, h:hemorrhage 4B-CP+GLY100 Group: Congestion, hemorrhage, edema, inflammation, degeneration, and desquamation, which are less severe than CP group. 5B-CP+GLY200 Group: A slightly lighter lesion than the CP+GLY100 group. 6B$C P+$ Mesna + GLY100 Group: Very mild vascular findings, epithelium is preserved. 7B-CP+Mesna + GLY200 Group: any microscopical lesion. 


\section{DISCUSSION}

The use of G. glabra root for medical purposes dates back to Christ (Akan and Balos 2008, Çınar 2012). This plant, which is widely used in our ancient medical tradition, is still used today (Uygun 2015). It has been reported that GLY, one of the active agents of this plant, inhibits coagulation and platelet aggregation in humans, and when combined with Bothrops jararaca snake venom in rats, it decreases the formation of thrombosis and also substantially eliminates venom-induced hemorrhages (Assafim et al. 2006). Glycyrrhizin which also has antiinflammatory properties (Francischetti et al. 1997), inhibits the migration of leukocytes to the site of inflammation via selectins (Rao et al. 1994). In experimental cerebral hemorrhage models of rats, GLY which reduces inflammation following hemorrhage (Ieong et al. 2018) and brain edema (Ohnishi et al. 2011), prevents possible brain injury.

In the light of the information given in the literatures; in this study, GLY, which is thought to reduce CP associated bladder lesions, was applied to animals at doses of 100 and $200 \mathrm{mg} / \mathrm{kg}$. At the end of the study, serosal, mucosal, and luminal hemorrhagic surface along with the thickness of the bladder wall were decreased as compared to the CP group. In the microscopical examination, it was observed that the symptoms such as inflammation, congestion, edema, and hemorrhage, which were severely formed in the CP group, were alleviated in animals treated with 100 $\mathrm{mg} / \mathrm{kg}$ GLY, and these lesions were very mild in 200 $\mathrm{mg} / \mathrm{kg}$ GLY treated animals.

In some experimental studies (Vieira et al. 2004, Kankaya 2017), the active ingredients were administered alone and/or combined with a single Mesna application for protection from precursor acrolein damage and successful results were reported from these studies. In accordance with these studies, we also examined 100 and $200 \mathrm{mg} / \mathrm{kg}$ GLY alone and in combination with Mesna to observe the success of the active substance in four groups of animals. The success of the GLY-Mesna combinations was higher than the groups treated with GLY alone, and there was a positive correlation with the increase in the dose of GLY.

Kankaya (2017), who analyzed ellagic acid in CPassociated HS model in rats, reported that this active substance yielded successful results both macroscopically and microscopically, and correlated this success with active substance-related antioxidant capacity. Ankaferd and epinephrine applications against CP have been reported to prevent congestion and edema in both agents (Kilic et al. 2016). It has been reported that Berberin completely blocked the bladder edema and hemorrhages at increasing doses of the CP-associated HS model (Xu and Malavé
2001). Mandevilla velutina has been shown to inhibit CP-associated HS (Santos et al. 2010). It was reported that CP-associated edema, hemorrhage, and congestion decreased in the bladder in different doses of resveratrol (Keles et al. 2014). In this study, hemorrhage were found to be at the Control group levels in GLY-Mesna combined groups. The high level of edema in low-dose GLY alone was similar to Control group and GLY-Mesna combined groups. Similar to other vascular findings, such as hemorrhage and edema, GLY-Mesna combinations were also beneficial in preventing congestion.

A positive condition has been reported in CPassociated bladder inflammation due to the action of ellagic acid (Kankaya 2017) The content of Mandevilla velutina has been shown to inhibit the inflammation of the bladder in experimental HS cases (Santos et al. 2010). Ipomoea obscura has been shown to have an antiinflammatory effect in this context (Hamsa and Kuttan 2011). Anti-inflammatory properties of Phyllanthus niruri plant were investigated by Boeira et al. (2011). In this study, it was found that antiinflammatory effect was limited in both doses of GLY alone, but anti-inflammatory effect was significant in GLY-Mesna combinations.

The combination of ellagic acid with Mesna was found to be favorable against CP-associated epithelial damage and degeneration (Kankaya 2017). Researchers who found Ankaferd and epinephrine effectivity in preventing necrosis and ulceration referred to Ankaferd for epithelial regeneration (Kilic et al. 2016). Curcuma longa content was reported to has been urothelial preservative in CP-induced HS (Arafa 2009). In this study, when degenerative and desquamative changes are considered, it was seen that GLY had a successful or contingent effect and this effect was quite high in GLY-Mesna combined groups.

In conclusion, CP-associated macroscopic and microscopic lesions in the bladder were observed to be quite mild in the groups treated with GLY alone, and GLY-Mesna combinations were found to have been even more advanced and also a positive correlation was observed for the increased dose. Mesna is administered by i.p. route in clinical applications. As known, the i.p. route means the maximum absorption rate and maximum quantity for many drugs and active substances after the intravenous (i.v.) route. Unfortunately, GLY is a substance that is not suitable for i.p. or i.v. administration and is required to administrate by g.g. in our study. In g.g. applications, bioavailability is very low compared to the previous administration routes and this g.g. route may limit the success achieved as a result of the study. We believe that more promising results can be achieved with the development of i.p. or i.v. forms of GLY. 


\section{ACKNOWLEDGEMENT}

Coordination Unit of Scientific Research Projects of Afyon Kocatepe University (Project number 16. SAG.BIL.15). This study is summarized in the MSc Thesis titled "Pathologic Examination of the Protective Effect of Glycyrrbizin on Cyclophosphamide-induced Hemorrbagic Cystitis in Rats. Afyon Kocatepe University Experimental Animal Research and Application Center with permission of AKUHADYEK477-15.

\section{REFERENCES}

Akan H, Balos M. GAP Bölgesi'nden toplanan meyan kökü (Glycrrbiza glabra L.) taksonunun ihracat durumu, etnobotanik özellikleri ve tıbbi önemi. Firat Üniversitesi Fen ve Mühendis Bilim Derg. 2008; 20(2):233-241. [in Turkish]

Arafa HMM. Uroprotective effects of curcumin in cyclophosphamide-induced haemorrhagic cystitis paradigm. Basic Clin Pharmacol Toxicol. 2009; 104(5):393-399.

Asımgil A. Şifalı Bitkiler. İstanbul: Timaş Yayınları; 1997. [in Turkish].

Asl MN, Hosseinzadeh H. Review of pharmacological effects of Glycyrrbiza sp. and its bioactive compounds. Phytother Res. 2008; 22(6):709-724.

Assafim M, Ferreira MS, Frattani FS, Guimarães JA, Monteiro RQ, Zingali RB. Counteracting effect of glycyrrhizin on the hemostatic abnormalities induced by Bothrops jararaca snake venom. Br J Pharmacol. 2006; 148(6):807-813.

Ballen KK, Becker P, Levebvre K, Emmons R, Lee K, Levy W, Stewart FM, Quesenberry P, Lowry P. Safety and cost of hyperhydration for the prevention of hemorrhagic cystitis in bone marrow transplant recipients. Oncology. 1999; 57(4):287-292.

Baytop T. Türkçe Bitki Adları Sözlügü. Ankara: Türk Dil Kurumu Yayınları; 1999a. [in Turkish].

Baytop T. Türkiye'de Bitkiler ile Tedavi Geçmişte ve Bugün. 2. baskı. Nobel Tip Kitapevleri; 1999b. [in Turkish].

Boeira VT, Leite CE, Santos AA, Edelweiss MI, Calixto JB, Campos MM, Morrone FB. Effects of the hydroalcoholic extract of Phyllanthus niruri and its isolated compounds on cyclophosphamide-induced hemorrhagic cystitis in mouse. Naunyn Schmiedebergs Arch Pharmacol. 2011; 384(3):265-275.

Çınar İ. Effect of temperature and time on licorice root (Glycyrrbiza glabra L.) extraction and modelling extraction kinetics. Electron J Food Technol. 2012; 7(2):21-30. [in Turkish with English abstract].

Del Pizzo JJ, Chew BH, Jacobs SC, Sklar GN. Treatment of radiation induced hemorrhagic cystitis with hyperbaric oxygen: long-term followup. J Urol. 1998; 160(3 Pt 1):731-733.

deVries CR, Freiha FS. Hemorrhagic cystitis: a review. J Urol. 1990; 143(1):1-9.

Dorris K, Fouladi M, Davies SM, Perentesis JP, Lawrence JM, Chow LML, Assa'ad A, Uygungil B, Jodele S. Severe allergic reactions to thiol-based cytoprotective agents mesna and amifostine in a child with a supratentorial primitive neuroectodermal tumor. J Pediatr Hematol Oncol. 2011; 33(6):e250-e252.
Francischetti IM, Monteiro RQ, Guimarães JA, Francischetti B. Identification of glycyrrhizin as a thrombin inhibitor. Biochem Biophys Res Commun. 1997; 235(1):259-263.

Goker H, Haznedaroglu I, Ercetin S, Kirazli S, Akman U, Ozturk Y, Firat H. Haemostatic Actions of the Folkloric Medicinal Plant Extract Ankaferd Blood Stopper ${ }^{\circledR}$. J Int Med Res. 2008; 36(1):163-170.

Gressier B, Lebegue N, Brunet C, Luyckx M, Dine T, Cazin M, Cazin JC. Scavenging of reactive oxygen species by letosteine, a molecule with two blocked-SH groups. Comparison with free-SH drugs. Pharm World Sci. 1995; 17(3):76-80.

Hamsa TP, Kuttan G. Protective role of Ipomoea obscura (L.) on cyclophosphamide-induced uro- and nephrotoxicities by modulating antioxidant status and pro-inflammatory cytokine levels. Inflammopharmacology. 2011; 19(3):155167.

Ieong C, Sun H, Wang Q, Ma J. Glycyrrhizin suppresses the expressions of HMGB1 and ameliorates inflammative effect after acute subarachnoid hemorrhage in rat model. J Clin Neurosci. 2018; 47:278-284.

Ito M, Sato A, Hirabayashi K, Tanabe F, Shigeta S, Baba M, De Clercq E, Nakashima $\mathbf{H}$, Yamamoto $\mathbf{N}$. Mechanism of inhibitory effect of glycyrrhizin on replication of human immunodeficiency virus (HIV). Antiviral Res. 1988; 10(6):289-298.

Kankaya A. Pathologic examination of the protective effects of ellagic acid on cyclophosphamide-induced hemorrhagic cystitis in rats. MSc thesis. Afyon Kocatepe University Health Science Institute, Afyonkarahisar, 2017. [in Turkish with English abstract].

Keles H, Bozkurt MF, Ulucan A, Demirel HH, Yuksel H, Karadas E, Ozkul IA. The role of inducible nitric oxide synthase in urinary bladders of cattle with enzootic hematuria and its struggle with uroplakin III. Ank Üniversitesi Vet Fakültesi Derg. 2018; 65(4):341-348.

Keles I, Bozkurt MF, Cemek M, Karalar M, Hazini A, Alpdagtas S, Keles H, Yildiz T, Ceylan C, Buyukokuroglu ME. Prevention of cyclophosphamideinduced hemorrhagic cystitis by resveratrol: a comparative experimental study with mesna. Int Urol Nephrol. 2014; 46(12):2301-2310.

Khaw SL, Downie PA, Waters KD, Ashley DM, Heath JA. Adverse hypersensitivity reactions to mesna as adjunctive therapy for cyclophosphamide. Pediatr Blood Cancer. 2007; 49(3):341-343.

Kilic O, Akand M, Karabagli P, Piskin MM. Hemostatic Efficacy and Histopathological Effects of Ankaferd Blood Stopper in an Experimental Rat Model of Cyclophosphamide-induced Hemorrhagic Cystitis. Urology. 2016; 94:313.e7-313.e13.

Kim S-H, Lee I-C, Lim J-H, Moon C, Bae C-S, Kim S-H, Shin D-H, Park S-C, Kim H-C, Kim J-C. Protective effects of pine bark extract on developmental toxicity of cyclophosphamide in rats. Food Chem Toxicol. 2012; 50(2):109-115.

Lin CY, Keefe M. Mesna-induced photodistributed dermatosis. Clin Exp Dermatol. 2012; 37(4):358-360.

Lin G, Nnane IP, Cheng TY. The effects of pretreatment with glycyrrhizin and glycyrrhetinic acid on the retrorsineinduced hepatotoxicity in rats. Toxicon. 1999; 37(9):1259-1270

Manikandan R, Kumar S, Dorairajan LN. Hemorrhagic 
cystitis: A challenge to the urologist. Indian J Urol. 2010; 26(2):159-166.

Ohnishi M, Katsuki H, Fukutomi C, Takahashi M, Motomura M, Fukunaga M, Matsuoka Y, Isohama Y, Izumi Y, Kume T, Inoue A, Akaike A. HMGB1 inhibitor glycyrrhizin attenuates intracerebral hemorrhage-induced injury in rats. Neuropharmacology. 2011; 61(5-6):975-980.

Oter S, Korkmaz A, Oztas E, Yildirim I, Topal T, Bilgic H. Inducible nitric oxide synthase inhibition in cyclophosphamide induced hemorrhagic cystitis in rats. Urol Res. 2004; 32(3):185-189.

Park KH, Zaichenko L, Brinkoetter M, Thakkar B, SahinEfe A, Joung KE, Tsoukas MA, Geladari EV, Huh JY, Dincer F, Davis CR, Crowell JA, Mantzoros CS. Circulating irisin in relation to insulin resistance and the metabolic syndrome. J Clin Endocrinol Metab. 2013; 98(12):4899-4907.

Philips FS, Sternberg SS, Cronin AP, Vidal PM. Cyclophosphamide and urinary bladder toxicity. Cancer Res. 1961; 21:1577-1589.

Ram A, Mabalirajan U, Das M, Bhattacharya I, Dinda AK, Gangal SV, Ghosh B. Glycyrrhizin alleviates experimental allergic asthma in mice. Int Immunopharmacol. 2006; 6(9):1468-1477.

Rao BN, Anderson MB, Musser JH, Gilbert JH, Schaefer ME, Foxall C, Brandley BK. Sialyl Lewis X mimics derived from a pharmacophore search are selectin inhibitors with anti-inflammatory activity. J Biol Chem. 1994; 269(31):19663-19666.

Santos AA, Leal PC, Edelweiss MIA, Lopes TG, Calixto JB, Morrone FB, Campos MM. Effects of the compounds MV8608 and MV8612 obtained from Mandevilla velutina in the model of hemorrhagic cystitis induced by cyclophosphamide in rats. Naunyn Schmiedebergs Arch Pharmacol. 2010; 382(5-6):399-407.

Shiota G, Harada K, Ishida M, Tomie Y, Okubo M, Katayama S, Ito $\mathbf{H}$, Kawasaki $\mathbf{H}$. Inhibition of hepatocellular carcinoma by glycyrrhizin in diethylnitrosamine-treated mice. Carcinogenesis. 1999; 20(1):59-63.

Sohn E-J, Kang D-G, Lee H-S. Protective effects of glycyrrhizin on gentamicin-induced acute renal failure in rats. Pharmacol Toxicol. 2003; 93(3):116-122.

Soysal T. Hemorrhagic cystitis. Blood and Bone Marrow Transplantation Course, Turkish Hematology Society. 2004. [in Turkish].

Uto T, Morinaga $\mathbf{O}$, Tanaka $\mathbf{H}$, Shoyama $\mathbf{Y}$. Analysis of the synergistic effect of glycyrrhizin and other constituents in licorice extract on lipopolysaccharide-induced nitric oxide production using knock-out extract. Biochem Biophys Res Commun. 2012; 417(1):473-478.

Uygun S. The licorice as the favorite plant of the westerners and the imperialist rivalry. OTAM. 2015; 37/Bahar:337-373. [in Turkish with English abstract].

Vieira MM, Macêdo FYB, Filho JNB, Costa ACLV, Cunha AN, Silveira ER, Brito GAC, Ribeiro RA. Ternatin, a flavonoid, prevents cyclophosphamide and ifosfamideinduced hemorrhagic cystitis in rats. Phytother Res. 2004; 18(2):135-141.

Wang C-Y, Kao T-C, Lo W-H, Yen G-C. Glycyrrhizic acid and 18ß-glycyrrhetinic acid modulate lipopolysaccharideinduced inflammatory response by suppression of NF- $x \mathrm{~B}$ through PI3K p1108 and p110 $\gamma$ inhibitions. J Agric Food
Chem. 2011; 59(14):7726-7733.

West NJ. Prevention and treatment of hemorrhagic cystitis. Pharmacotherapy. 1997; 17(4):696-706.

Xu X, Malavé A. Protective effect of berberine on cyclophosphamide-induced haemorrhagic cystitis in rats. Pharmacol Toxicol. 2001; 88(5):232-237. 